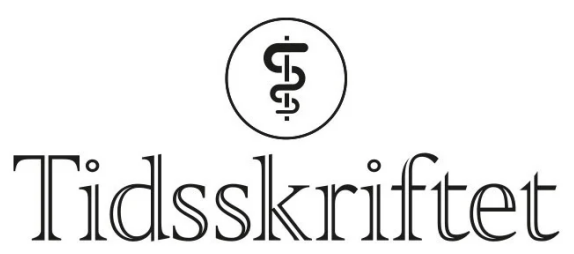

DEN NORSKE LEGEFORENING

\title{
Sars-CoV-2-infeksjon under svangerskapet
}

DEBATT

\section{HILDE ENGJOM}

hilde.engjom@gmail.com

Hilde Engjom er ph.d. og gynekolog ved Kvinneklinikken, Haukeland universitetssjukehus og overlege ved Avdeling for helseregisterforsking og -utvikling, Folkehelseinstituttet.

Forfattaren har fylt ut ICMJE-skjemaet og oppgir ingen interessekonfliktar.

\section{PÉTUR BENEDIKT JULIUSSON}

Pétur Benedikt Juliusson er ph.d. og barnelege ved Haukeland universitetssjukehus, fagdirektør i Avdeling for helseregisterforsking og -utvikling, Folkehelseinstituttet, og professor ved Universitetet i Bergen.

Forfattaren har fylt ut ICMJE-skjemaet og oppgir ingen interessekonfliktar.

\section{Det er lite kunnskap om korleis infeksjon med sars-CoV-2 kan påverke tilstanden til mor og barn. No er det sett i gang ei utvida datainnsamling om gravide som vert innlagt på sjukehus.}

Ved utbrotet av influensa $\mathrm{A}\left(\mathrm{H}_{1} \mathrm{~N}_{1}\right)$-pandemien - svineinfluensaen - for ti år sidan vart det klart at gravide kvinner var særleg sårbare, med ein auke i alvorleg maternell og perinatal sjukdom og dødelighet (1-4). . Norske registerdata frå utbrotet gav seinare eit godt kunnskapsgrunnlag for å tilrå gravide vaksinasjon mot influensa (5). Alvorleg sjukdom hos kvinna og komplikasjonar i svangerskapet ved infeksjon med sars-CoV-1 og mers-CoV har òg vore rapportert i kasuistikkar og sjukehusbaserte pasientseriar (ㅁ-9.).

Ettersom sars-CoV-2 er eit nytt virus, har vi lite kunnskap om korleis infeksjonen påverkar kvinna og fosteret. Det er publisert pasientseriar frå tidleg fase i pandemien som skildrar behov for oksygenbehandling, intensivbehandling og seier noko om utfall for dei nyfødde (10-12). Slike studiar kan raskt gi oversikt over behandlingsbehov, men har ikkje kontrollgrupper og er sårbare for seleksjonsskeivdeling (bias). Det trengst eit betre, populasjonsbasert datagrunnlag for å vurdere effekt av støttande behandling for gravide som treng sjukehusinnlegging, og for å sjå korleis intensivbehandling er relatert til behov for å forløyse kvinna eller utfall for fosteret dersom svangerskapet held fram. 
Alle fødslar i Noreg vert meldt til Medisinsk fødselsregister. Fødselsmeldinga innheld informasjon om kvinna si helse før og under svangerskapet, komplikasjonar under fødselen og helsa til kvinna og barnet etter fødselen. Meldinga vert sendt frå fødeinstitusjonane etter fødselen og er dermed ikkje eigna til rask overvaking av kvinna si helse under svangerskapet. Folkehelseinstituttet er ansvarleg for registeret og har iverksett utvida datainnsamling om gravide med covid-19 som vert innlagt på sjukehus.

\section{«Det trengst eit betre datagrunnlag for å vurdere effekt av støttande} behandling til gravide som treng sjukehusinnlegging»

Folkehelseinstituttet har bede alle fødeinstitusjonane om å utnevne ein kontaktperson som varslar instituttet dersom ei kvinne med covid-19 vert innlagt. Koordinator ved Folkehelseinstituttet vil deretter ta kontakt for å registrere utfyllande informasjon om symptom og behov for støttande behandling samt utfall for barnet. Datainnsamlinga har heimel i forskrift om Medisinsk fødselsregister, og journalopplysningar kan dermed hentast utan kvinna sitt samtykke.

Ved sjeldne tilstandar er internasjonal samordning viktig for å sikre samanliknbare tal og kunne overvake sjeldne og alvorlege tilstandar. Den utvida datainnsamlingen ved Medisinsk fødselsregister er difor utforma etter ein mal frå The International Network of Obstetric Survey Systems (13)_.Malen er tilpassa norske helseregister i samarbeid med nasjonale fag- og forskingsmiljø, og tilsvarande datainnsamling er planlagt i dei andre nordiske landa.

Den første populasjonsbaserte rapporten som bygger på dette rammeverket, vart nyleg publisert frå den britiske gruppa (14). 40 av totalt 427 kvinner ( $9 \%$ hadde behov for respirasjonsstøtte i intensivavdeling, fire av desse fekk behandling med hjarte-lungemaskin. Fem kvinner døydde, letaliteten (case fatality rate) var 1,2 \%, og sars-CoV-2-assosiert mødredødelegheit 5,6 per 100 ooo fødslar. Forekomst av spontanabort, dødfødsel og nyfødtdødsfall var hyppigare enn i kontrollgruppa, men på grunn av små tal var skilnadene ikkje statistisk signifikante. Ei datainnsamling i Noreg vil gi viktig informasjon om forholda her i landet.

\section{LITTERATUR}

1. Siston AM, Rasmussen SA, Honein MA et al. Pandemic 2009 influenza A(H1N1) virus illness among pregnant women in the United States. JAMA 2010;303: 1517-25. [PubMed][CrossRef]

2. Pierce M, Kurinczuk JJ, Spark P et al. Perinatal outcomes after maternal 2009/H1N1 infection: national cohort study. BMJ 2011;342: d3214. [PubMed][CrossRef]

3. Donaldson LJ, Rutter PD, Ellis BM et al. Mortality from pandemic A/H1N120og influenza in England: public health surveillance study. BM] 2009; 339: b5213. [PubMed][CrossRef]

4. European Center for Disease Prevention and Control. Poor pregnancy outcomes associated with maternal infection with the $\mathrm{A}\left(\mathrm{H}_{1} \mathrm{~N}_{1}\right) 2009$ virus during the pandemic - findings from a European cohort study. https://www.ecdc.europa.eu/en/news-events/poor-pregnancy-outcomes-associatedmaternal-infection-ah1n1-2009-virus-during-pandemic Lest 23.6.2020.

5. Håberg SE, Trogstad L, Gunnes N et al. Risk of fetal death after pandemic influenza virus infection or vaccination. N Engl J Med 2013; 368:333-40. [PubMed][CrossRef]

6. Ng WF, Wong SF, Lam A et al. The placentas of patients with severe acute respiratory syndrome: a pathophysiological evaluation. Pathology 2006; 38: 210-8. [PubMed][CrossRef]

7. Assiri A, Abedi GR, Al Masri M et al. Middle East Respiratory Syndrome Coronavirus Infection During Pregnancy: A Report of 5 Cases From Saudi Arabia. Clin Infect Dis 2016; 63: 951-3. [PubMed] [CrossRef]

8. Wong SF, Chow KM, Leung TN et al. Pregnancy and perinatal outcomes of women with severe acute respiratory syndrome. Am J Obstet Gynecol 2004; 191: 292-7. [PubMed][CrossRef] 
9. Payne DC, Iblan I, Alqasrawi S et al. Stillbirth during infection with Middle East respiratory syndrome coronavirus. J Infect Dis 2014; 209: 1870-2. [PubMed][CrossRef]

10. Chen H, Guo J, Wang C et al. Clinical characteristics and intrauterine vertical transmission potential of COVID-19 infection in nine pregnant women: a retrospective review of medical records. Lancet 2020; 395: 809-15. [PubMed][CrossRef]

11. Liu Y, Chen H, Tang K et al. Clinical manifestations and outcome of SARS-CoV-2 infection during pregnancy. J Infect 2020; So163-4453(20)30109-2. [PubMed][CrossRef]

12. Ferrazzi E, Frigerio L, Savasi V et al. Vaginal delivery in SARS-CoV-2-infected pregnant women in Northern Italy: a retrospective analysis. BJOG 2020; 1471-0528.16278. [PubMed][CrossRef]

13. International Network of Obstetric Survey Systems (INOSS). https://www.npeu.ox.ac.uk/inoss Lest 23.6.2020.

14. Knight M, Bunch K, Vousden $\mathrm{N}$ et al. Characteristics and outcomes of pregnant women admitted to hospital with confirmed SARS-CoV-2 infection in UK: national population based cohort study. BMJ 2020;369: m2107. [PubMed][CrossRef]

Publisert: 16. juli 2020. Tidsskr Nor Legeforen. DOI: 10.4045/tidsskr.20.0489

Mottatt 1.6.2020, første revisjon innsendt 13.6.2020, godkjent 23.6.2020.

(C) Tidsskrift for Den norske legeforening 2023. Lastet ned fra tidsskriftet.no 26. april 2023. 